\begin{tabular}{c}
\hline Review of \\
ECONOMICS \\
and \\
INSTITUTIONS
\end{tabular}

Review of Economics and Institutions ISSN 2038-1379 DOI:10.5202/rei.v9i1.272

Vol. 9 - No. 1, Spring-Summer 2018 - Article 1

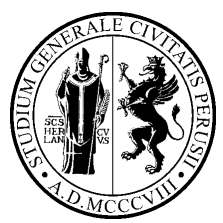

www.rei.unipg.it

\title{
Investing in Innovation and Skills: Thriving through Global Value Chains
}

\author{
Luca Marcolin $\bowtie$ \\ $O E C D$
}

\author{
Mariagrazia Squicciarini \\ OECD
}

\begin{abstract}
This paper investigates empirically the interplay between participation and positioning in global value chains (GVCs), employment demand and supply and workforce's skills endowment. Results touch upon the way innovation, technology and participation in GVCs shape employment in routine intensive and non-routine jobs; the relationship between participation in GVCs and polarisation of employment; the way the skill composition of a country's workforce - both the type of skills and their distribution - shapes specialisation and positioning along GVCs; and the complementarities emerging between GVC participation and investment in knowledge-based capital, especially organisational capital and ICT.
\end{abstract}

JEL classification: J20; O33; F16; F66; E22; L23

Keywords: Global Value Chains; Labor Demand; Skills; Intangible Assets; Innovation.

The present analysis expresses only the authors' views and does not necessarily reflect the official views of the institutions where the authors are affiliated. The authors retain all responsibilities for errors and omissions in this document.

$\bowtie$ Address: Science, Technology and Innovation Directorate, 2, rue André Pascal, 75016 Paris, France. Email: luca.marcolin@oecd.org

\section{Recommended Citation}

Marcolin, L., Squicciarini, M., (2018). Investing in Innovation and Skills: Thriving through Global Value Chains. Review of Economics and Institutions, 9(1), Article 1. doi: 10.5202/rei.v9i1.272

Retrieved from http://www.rei.unipg.it/rei/article/view/272 


\section{Introduction}

Over the last decades, the world has witnessed an ever growing movement of capital, intermediate inputs, final goods and people. Technological progress, innovation, and trade and investment liberalisation, among others, have led to an operational and geographical unbundling of production which makes it possible to produce and assemble parts of goods and services in distant locations, often geographically clustered at the local and regional level (Baldwin, 2012). Such fragmented production patterns happening in the context of greater international economic integration are generally termed global value chains (GVC), to emphasise the value added generated over the production chain.

GVCs contribute to make an efficient use of a country's resources by exchanging its goods and services for those that a counterpart produces relatively more efficiently, and ultimately shape countries' (regions') economic growth and welfare. At the same time as production becomes progressively unbundled across borders, countries and regions become economically more integrated through complex networks of investment, products and human capital. These affect productivity and the efficient allocation of inputs; the demand for skills and the skill composition of the workforce; the generation, diffusion and adoption of technologies; and the income of households. These dynamic gains from trade strengthen the argument that trade reflecting the comparative advantage is not a zero-sum game.

While being potentially able to benefit all parties involved, GVCs often lead to gains that are unevenly distributed within and across countries. Market failures including rigid labour and product markets, credit market imperfections, and knowledge and networks externalities, may interfere with the appropriation of the overall gains. Also, interconnectedness and the increased volatility and uncertainty that may come with it, may affect some parts of the population more than others, and change the quality and allocation of production inputs. Increased access to global markets, also by developing countries, has greatly expanded the global workforce, making it more convenient for producers in developed countries to outsource or offshore part of the production. Similarly, producers in OECD countries have been facing increasing competition on final product markets, due to imports from an ever greater set of producing countries. Both patterns are likely to have contributed to employment polarisation (e.g. Goos et al., 2014), general downward pressure on wages, especially of unskilled workers, and the observed decline in manufacturing employment in OECD countries (e.g. Ebenstein et al., 2014; Autor et al., 2016; Keller and Utar, 2016).

While these distributive outcomes can result out of complex phenomena that unfold independently on trade, including limited social and geographical mobility, low growth, or technological change, public scepticism about the possible benefits of trade and globalisation has been growing. Despite the fact that inequalities have been increasing in the 
context of a sizeable slowdown of global trade growth in recent years (ECB, 2016; Haugh et al., 2016), a recent survey (Pew Research Center, 2014) carried out across 44 countries highlighted that a significant number of people in OECD countries felt left behind by globalisation. While median respondents in advanced nations thought that trade was good for their countries ( $84 \%$ agree), they also believed that globalisation hardly increased employment (44\% agree) or wages (25\%). Several studies further correlate discontent towards trade to increased support in populist or protectionist parties (Dippel et al., 2015; Autor et al., 2016; Colantone and Stanig, 2016; Malgouyres, 2016; Jensen et al., 2018).

Allowing citizens to benefit from the opportunities that globalisation offers therefore requires integrated policy approaches. This on the one hand entails creating the right conditions for the potential benefits of openness and interconnectedness to materialise, for instance through investment in education and innovative capabilities or improvements in credit and labour markets. On the other hand, mechanisms aimed at redistributing the gains of globalisation to those who are left behind and whose jobs and lives are disrupted by it should be devised. This may mean, for instance, providing people with the 'right' set of skills, supporting income in job-to-job transitions, and strengthening social safety nets. While the present study does not offer evidence on the role of policies explicitly, it nevertheless suggests a number of measures which could affect the economic relationships analysed empirically.

The work carried out in the context of the OECD GVCs, Jobs and Skills project ${ }^{1}$ has contributed to shed light on these issues, by providing evidence about the effect of GVC participation on jobs and employment, and the way workforce skills shape countries' participation in GVC. This article highlights some of the policy implications related to the way in which innovation, technology and GVC participation shape employment in routine intensive and non-routine jobs; and the relationship between participation in GVCs and the polarisation of employment, i.e. a situation in which one observes job losses in the middle of the wage or skill distribution and job gains at the extremes of these distributions. The note further addresses how the skill composition of a country's workforce both the type of skills and their distribution - shapes specialisation and positioning along the global value chain. Finally, the way in which GVC specialisation and positioning both determine and are determined by investment in selected knowledge-based capital (KBC, also known as intangible) assets, and what this entails for policy will be discussed.

1 The "GVCs, jobs and skills" project was carried out by the Directorate for Science, Technology and Innovation (STI) in collaboration with the Directorate for Education and Skills (EDU), the Employment, Labour and Social Affairs Directorate (ELS) and the Trade and Agriculture Directorate (TAD). 


\section{How Many and Which Jobs in GVCs?}

The rapid pace of growth of trade of the last three decades saw an increasing participation of developing countries in global exports. While in the 1990s North-South trade represented a limited proportion of global trade, this is no longer the case. For the EU15, for instance, the proportion of North-North imports in total imports of manufactured goods (including intra-EU trade) declined from $91 \%$ in 1990 to $71 \%$ in 2015 (Crozet and Orefice, 2017). Trade with low-wage countries, coupled with the diffusion of labour-saving technologies, is considered one of the drivers of the current restructuring of employment across occupations and sectors in OECD countries, and of the historical decline of manufacturing employment.

To shed light on the way in which GVC participation shapes employment levels and distribution two complementary analyses have been carried out. The first assesses the importance of GVC trade on jobs of different routine intensity (Marcolin et al., 2016 and 2018a). The second revisits the import competition hypothesis and existing evidence related to the so-called polarisation of the labour market (Breemersch et al., 2017). Employment polarisation is characterised by employment loss in the middle of the wage or skill distribution and by increases in employment levels at the extremes of these distributions (see e.g. Autor et al., 2003; Goos et al., 2014). It emerges from differences in the complementarity of labour-saving technologies with mid-skilled employment (negative complementarity) and skilled employment (positive complementarity), and a positive complementarity between employment at the top and bottom of the skill distribution.

\subsection{The Trade and Jobs Nexus in the Literature}

In the '90s many studies explored the consequences of competition from developing countries on employment and wage inequality in developed countries. They posited that, if imports from developing countries concentrate in industries intensive in unskilled labour, import competition may negatively affect the wages of unskilled workers relative to skilled workers in developed countries and, through this income effect, raise the employability of unskilled workers. The evidence collected in the 1990s and early 2000s, however, supported the idea that job losses in manufacturing were rather linked to technological advancements and reduced labour demand in manufacturing, rather than trade (e.g. Berman et al., 1994; 1998). Skill-complementary technological progress in the form of computerisation increased wage inequality and skill intensity.

A separate set of studies focusing on offshoring of intermediate inputs linked changes in trade to employment or wages. It was argued that when production of low-skill or low-wage intensive intermediate inputs is relatively cheaper in developing countries, developed countries' firms outsource the production of low-skilled-intensive goods to developing countries, thus freeing resources to hire further skilled workers at home. Feenstra and Hanson (1999), for instance, found that computerisation 
affected demand for skilled labour in the US in the 1990s more strongly than offshoring, but that both channels were active. Grossmann and Helpman (2008) further proposed to divide production in a continuum of tasks (rather than products), and argued that the more routine intensive tasks would be offshored. The analysis here below embraces this task-based perspective of production, whereby final goods are assembled from a number of separable intermediate products or tasks which can be produced or carried out in different countries, sequentially or simultaneously.

The surge of Chinese exports during the 2000s motivated a third group of analyses which tested the conclusions of studies focused on the labour market outcomes of technology and trade. They found evidence about import competition from the People's Republic of China (hereafter China) having a sizable negative effect on the labour market of developed countries (e.g. Ebenstein et al., 2014; Autor et al., 2013; Autor et al., 2016). Also, it was found that GVCs have become more capital and high-skill intensive after 2001, when freer access to the Chinese market allowed for important capital inflows into the country and accelerated the erosion of developed economies' comparative advantage in labour-intensive production (Timmer et al., 2014). These studies generally allow the impact of Chinese trade to originate both from increased competition on the final goods market, and by offshoring of intermediate good production to China.

\subsection{Routine Jobs and Technology}

Marcolin et al. (2018s) develop new indicators of the routine intensity of occupations based on information from the OECD Programme for the International Assessment of Adult Competencies (PIAAC). These measures capture individual workers' degree of independence in planning and organising their activities and time, as well as their freedom in deciding what to do on the job and in what sequence. They further distinguish between the tasks workers do on their jobs and the skills they are endowed with. Statistics based on these indicators shed light on the extent to which average industry intensity in routine tasks differs across countries (Figure 1). While routine-intensive jobs are generally associated with relatively lower skill levels, yet, there exist skilled workers who carry out routine jobs (e.g. medical imaging technicians), which can be affected by automation and relocation in the same way as low skill routine workers can. 
Figure 1. Percentage of Employment, by routine intensity. All PIAAC countries, 2011-2012

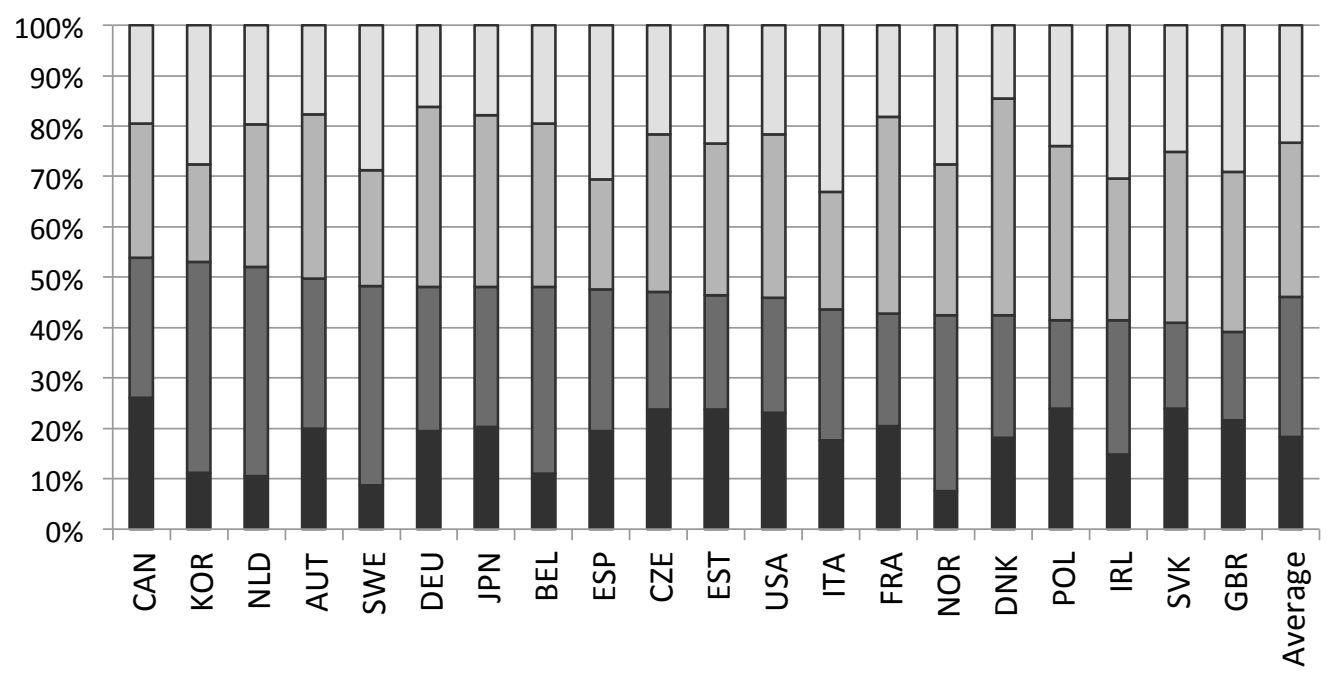

Q1: Low routine intensity

$\square$ Q2: Medium-low routine intensity

$\square$ Q3: Medium-high routine intensity $\square$ Q4: High routine intensity

Source: Marcolin et al. (2018a) based on PIAAC data.

Marcolin et al. (2016) further explore the extent to which employment levels of different routine jobs are shaped by industrial structure, technology and innovation capabilities, workforce skills and participation in GVCs. The analysis, which encompasses 27 European countries and the U.S. over 2000-2011 explores several trade in value-added (TiVA) patterns, including offshoring of inputs, domestic outsourcing, and offshoring of final assembly activities.

The results suggest the existence of complex interactions: a higher ICT intensity of industries is positively associated with employment, except for high-routine jobs, where ICTs seemingly displace workers (Figure 2). Conversely, technological intensity in the form of innovation output (i.e. patents), is found to relate positively to jobs of any routine intensity. 
Figure 2. Employment levels and ICT intensity: controlled correlations
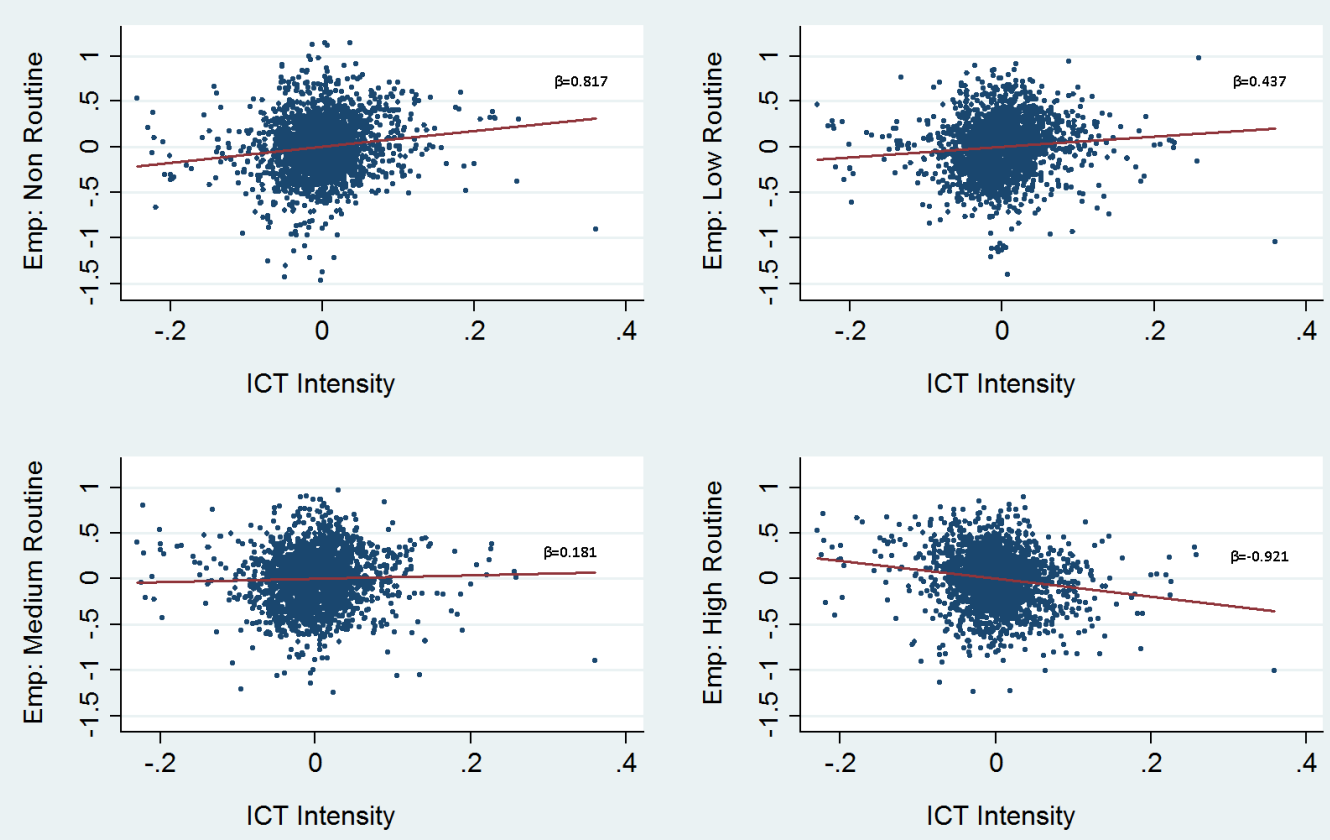

Note: The X-axis displays the share of employees in ICT occupations over total employment in the country-industry-pair. The $\mathrm{Y}$-axis shows the log-employment by routine intensity in each country-industry pair. All other factors included in the econometric analysis in Marcolin et al. (2016) are controlled for. Dots correspond to the residual of an OLS regression of the actual value on all other explanatory variables included in the analysis, except for the one plotted on the X-axis.

Source: Marcolin et al. (2016) based on European Labour Force Survey and U.S. Current Population Survey data.

GVCs generally do not seem to displace routine workers, especially in manufacturing, where input offshoring and domestic outsourcing are positively associated with routine employment. The opposite is conversely observed in the case of offshoring of final assembly and outsourcing of service inputs. Also, in manufacturing, the presence of large firms is positively associated with employment in routine occupations. More generally, industry structure seems to matter and so do economies of scale when competing in global markets: small is not always beautiful, and competition, while likely to improve allocation of resources and aggregate productivity, can bring about important job losses and lead to significant adjustment costs. Finally, while generally positively associated with employment, the role played by higher-level skills differs in manufacturing and services industries. While Marcolin et al. (2016) explore these complex relationships and their intuition in greater detail, it remains generally true that GVCs play a minor role in the dynamics of 
employment by routine type relative to other industry-level features and to technology in particular.

\subsection{Labour Market Polarisation}

The concept of routine tasks gained importance when Autor et al. (2003) highlighted that computerisation may have facilitated the automation of routine tasks and the progressively polarisation of labour markets in developed countries. Polarisation takes the form of job growth in relatively high-skill, high-wage jobs and low-skill, low-wage jobs. While job polarisation was first attributed to skill-biased technological change (Autor and Katz, 1999), recent work has shifted the focus towards the offshoring of routine tasks (Oldenski, 2014), or to Chinese import competition (Autor et al., 2013; Keller and Utar, 2016)2.

Breemersch et al. (2017) explore the role of all the mentioned channels in determining labour market polarisation in 19 European countries, between 1996-2007. Departing from most existing studies, the authors (i) explore both manufacturing and service employment; (ii) exploit measures of trade in value added; and (iii) look at the role of labour market institutions in mediating the impact of both technological progress and GVCs in employment polarisation.

Cross-country results suggest that while employment polarisation can be found in most countries covered by the study, differences emerge in the magnitude of the phenomenon. Also, in some countries, a decrease of low-paying occupations can be observed. Within countries, polarisation is found to have increased in almost all industries, and more so in business services than manufacturing. Increases in polarisation at the country level are thus the result of polarisation within individually considered industries and of changes in employment away from industries that are initially not-so-polarised to industries that are more polarised.

Figure 3 highlights that the within-industry component is the most important contributor to overall polarisation. On average, it explains $68 \%$, or 4.3 of the 6.3 percentage-point increase of employment in top and bottom (by wage) occupations in European countries. Manufacturing and wholesale and retail trade seem to drive the within-components, while the between-industry components are linked to employment being reallocated away from manufacturing to business services and also to health and social work.

2 The project left the exploration of wage dynamics (in the spirit of e.g. Ebenstein et al., 2014; Autor, 2015) to future research. 
Figure 3. Within/between-sector decomposition of polarisation

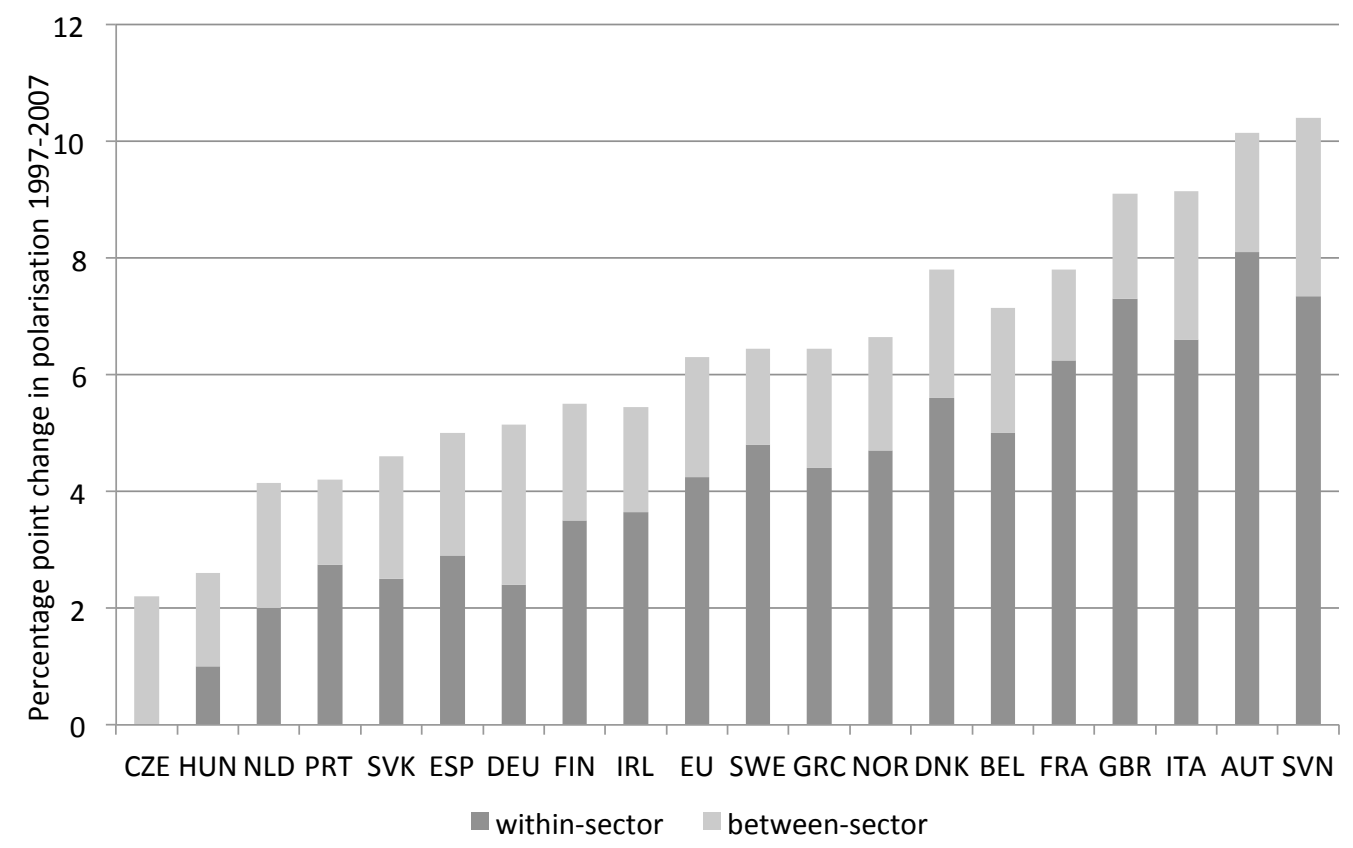

Source: Breemersch et al. (2017) based on European Labour Force Survey.

The analysis in Breemersch et al. (2017) suggests technological change to be once again the main driver of employment changes, and of within-industry polarisation in particular. Import competition from China is negatively but weakly correlated with polarisation in manufacturing. The same applies between offshoring of value added and polarisation in non-manufacturing industries. Somewhat surprisingly, labour market institutions contribute marginally to explain the different employment polarisation patterns emerged across countries. However, this may not be the case for wage polarisation, which remains outside the scope of the study.

In sum, both Marcolin et al. (2016) and Breemersch et al. (2017) align with existing evidence and find offshoring and trade to only play a limited role in shaping employment in OECD countries. It is changes in the technological endowment of the sector(s) and country(s) which are more significantly associated with changes in employment.

While important and robust, these conclusions need to be qualified by some caveats, given that both analyses do not take into account three aspects of trade, technological change and employment dynamics. First, GVCs can have an impact on employment dynamics through technological change, to the extent that high tech foreign intermediate and final goods can penetrate the domestic economy through international trade. Second, the role of technological change and innovation is bound to continuously change, given that technology diffuses and is absorbed at a different pace across industries and countries. Such a feature may change the conclusions of the analyses, although likely in the direction of a 
stronger role of technology, once the deployment of the latest labour-saving technologies is completed. Lastly, both changes in GVC participation and technology, especially if combined with good managerial practices, can improve within industry (firm) productivity and across-industry (firm) allocative efficiency, which in turn could free resources to hire new workers in the economy or industry. The studies above do not disentangle the direct employment creation or destruction effect of trade and technology from the general equilibrium positive effect on job creation discussed above.

\subsection{Trade in Employment}

A positive impact of GVCs on employment can be generated when firms scale up following an expansion in export markets. However, empirical evidence (e.g. Hoeckman and Winters, 2005) has thus far found little support for this so-called Heckscher-Ohlin prediction (Heckscher et al., 1991), whereby trade would redistribute employment away from import-substituting towards export-oriented productions, independently of changes in productivity. Most of the gains from trade to employment seem to manifest in higher productivity and economic growth, similar to what was mentioned in the previous section.

Independent of the channel, it is possible to estimate the share of domestic jobs used in production to satisfy foreign demand for final goods and services. Based on the Inter-Country Input-Output (ICIO) Database, the OECD has developed indicators providing insights into the origins of demand for a country's employment. The Trade in Employment Database offers employment by industry data for all OECD, EU28 countries and G20 countries. To produce measures of jobs sustained by foreign final demand it is assumed that foreign demand is satisfied by workers that use a proportion of their working time which is the same as the share of foreign demand in an industry's total output. For example, if one third of the output of a given industry is consumed abroad, then it is assumed that workers in that industry use one third of their time to sustain foreign final demand ${ }^{3}$. The numbers are important. For the last available year in the dataset, 2011, foreign demand sustained as many as 106.6 million workers over all OECD countries (61 million jobs in the EU28) in all sectors of the economy, of which 31.5 million in manufacturing (18.5 million in the EU28). Figure 4 shows the same numbers, but as a percentage of a country's or an industry's total employment, averaged over all countries in the macro-area. Foreign final demand is more important for

3 Changes in the number of jobs sustained by final demand therefore reflect the fluctuation in demand, and do not necessarily imply changes in the total number of workers effectively employed in the industry of interest.

4 Foreign final demand includes all countries but the one in consideration. For example, foreign demand for Austrian employment encompasses demand from any other country which is not Austria, including other European ones. 
manufacturing employment than for total economy employment, consistent with the higher trade propensity of the manufacturing sector. It is also more important for the average European country (56.6\% of total economy employment) than for the average OECD (53.7\%) or G20 (35.6\%) country. This dependency on foreign demand varies across countries, but it is less important for G20 countries than for the EU28 or the OECD.

As mentioned, the long term decline in manufacturing jobs in OECD countries has multiple causes. One of them is the decline in demand for manufacturing goods at home and from abroad, both in terms of direct demand for final manufacturing goods and of demand for intermediate goods embodied in the production of other sectors.

Figure 4. Jobs sustained by foreign final demand, as a percentage of total employment in the industry or economy (Average value of country-specific percentages, for all countries in the macro-area, 2011)

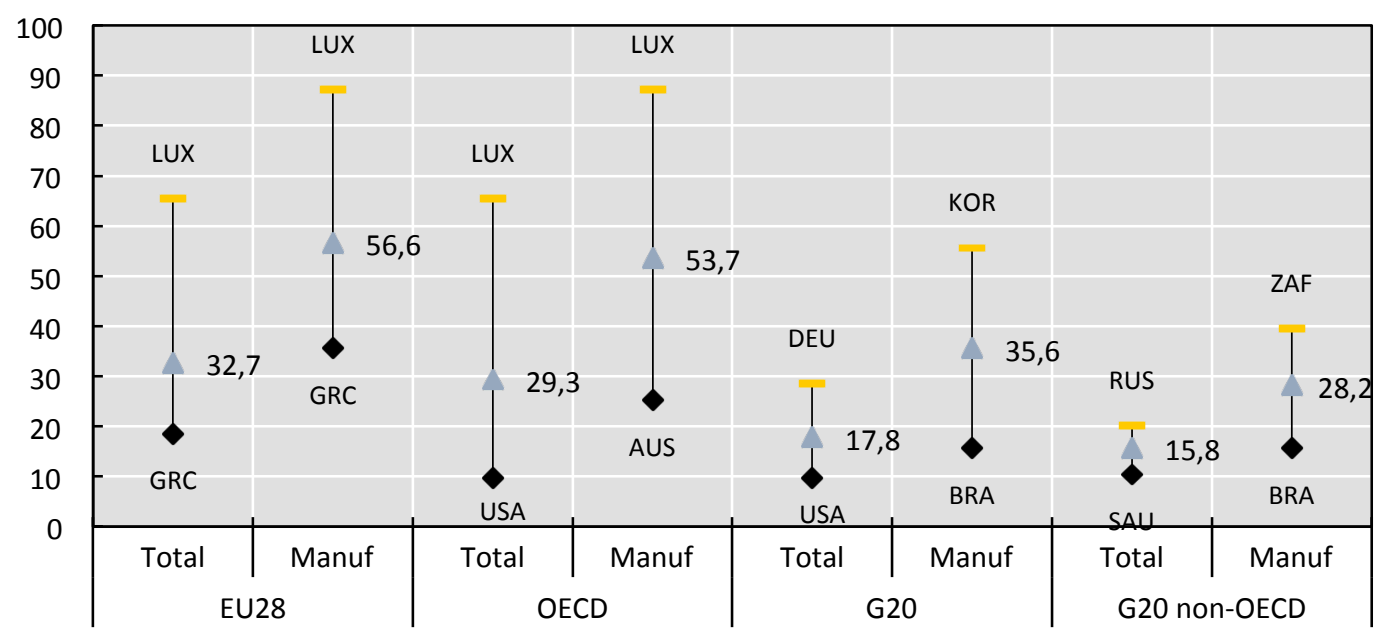

Note: OECD Trade in Employment database, accessed March 2017. Total stands for all sectors in the economy excluding household production, Manuf for sectors ISIC rev.3 number 15 to 37. Mean is calculated as unweighted average across the percentages of all countries in the macro-area of interest. The category G20 non-OECD includes Argentina, Brazil, China, India, Indonesia, the Russian Federation, Saudi Arabia and South Africa. EU28 and OECD have the same maximum and minimum values, which are the percentages for Luxembourg.

Source: Authors' calculations on OECD Trade in Employment database.

Figure 5 shows a decomposition of year-on-year changes in employment in manufacturing based on the origin of final demand for goods and services across different countries. For example, during the financial crisis which hit South-East Asia in 1997, net employment growth in the OECD was almost zero. However, this number was the result of an increase of about 2.6 million jobs created to meet demand in the European 
Union and the United States, and of a loss of about 2.5 million jobs due to lower demand for OECD-produced manufacturing goods from Southeast Asian countries (excluding China). In the same period covered by Figure 5 (1995-2011), over all OECD countries, manufacturing employment as a percentage of total employment decreased from $17.5 \%$ to $12.4 \%$.

Figure 5. Origin of demand for manufacturing jobs in OECD, annual changes by region of demand, 1995-2011

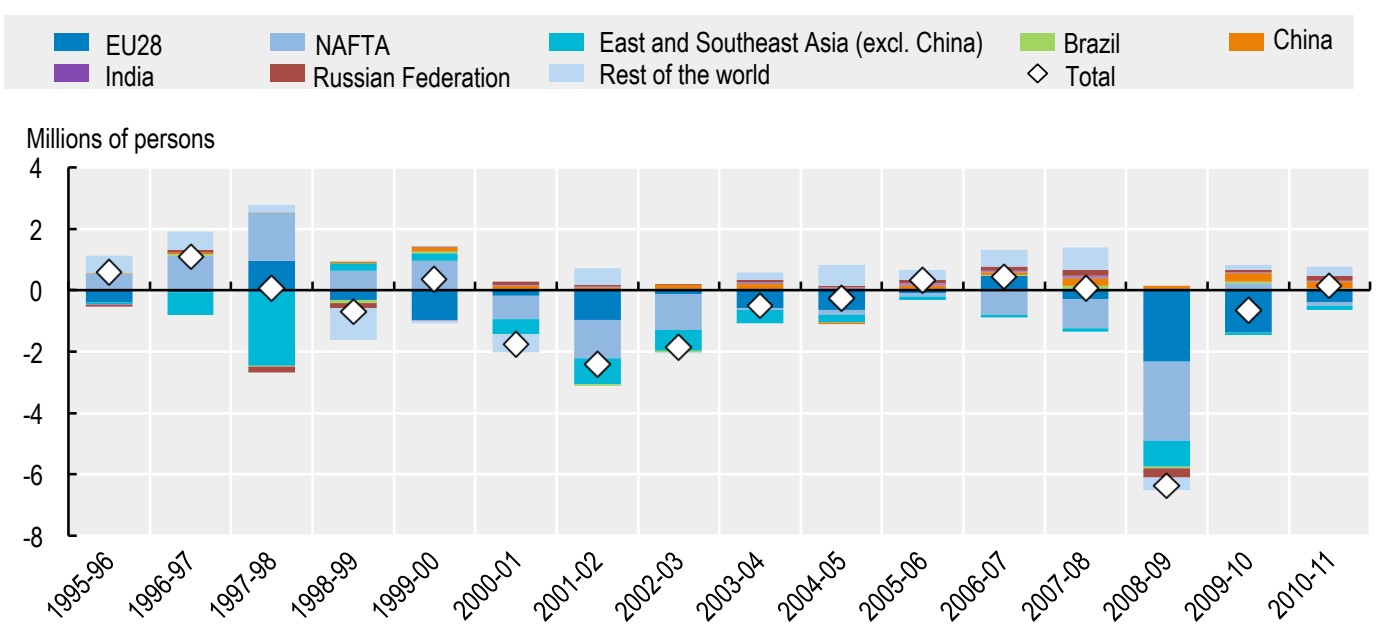

Note: East and Southeast Asia (excluding China) comprises Brunei Darussalam, Cambodia, Indonesia, Hong Kong (China), Japan, Korea, Malaysia, Philippines, Singapore, Chinese Taipei, Thailand and Viet Nam.

Source: OECD STI Scoreboard 2015, based on Inter-Country Input-Output (ICIO) Database, Structural Analysis (STAN) Database, Annual National Accounts Database, and World Input-Output Database (WIOD).

Participation in GVC entails a certain degree of specialisation. Some countries will tend to specialise in activities with different degrees of labour intensity, independently of whether this means specialising in high- or low-value added activities, whereas for others GVC participation might be associated with a switch from labour-intensive to capital-intensive activities, or from low-skill to high-skill intensive operations. The analyses presented above further suggest that there will be differences in the employment effects of GVCs depending on whether an economy is relatively larger and more service oriented, or whether it is catching-up and transiting towards a full market economy.

As many are the factors that jointly determine trade specialisation and employment dynamics, trade policy alone may be unable to reverse some of these trends, which appear to be explained by more profound determinants, including the skill distribution of the workforce, technology endowment, and innovation capabilities. Coordinated policy approaches are therefore needed to boost economic performance and minimise the cost of employment reallocation related to GVC participation. These 
approaches encompass industrial, innovation, labour, trade and skills policies.

Employment losses in manufacturing do not need to entail a net loss of employment for the economy as a whole, as lower manufacturing employment may be compensated by higher employment in services industries. The progressive servitisation of economies and the possible important productivity gains created by it need to be taken into account when designing effective policies.

The positive correlation of innovation with employment, and generally more so in the case of non-routine and low routine intensive occupations, argues in favour of policies supporting investment in innovation-related activities, and calls for the need to design broad-based innovation policies able to foster productivity and growth (OECD, 2015b). Among these policies, special attention could be given to the funding of research and the strengthening of research collaborations between universities and firms and between firms.

ICT-related capabilities appear to be positively correlated with employment of all routine intensities, except for high-routine workers. While it is unlikely that any policy may be able (or may want to) influence the routine-intensity and computerisation of employment, targeted skill policies can help sustain employability, especially if the ICT capabilities of workers are called into cause. This last point is discussed in more detail in the next session.

Policies affecting firm creation and scaling up processes would need to be carefully designed, too, as they may shape employment in opposite directions, depending on the concerned occupations and industries. For instance, in Marcolin et al. (2016), the presence of big firms in manufacturing correlates positively with higher employment of routine workers, whereas this is not the case in services. Hence, scaling up policies might have differential effects on aggregate employment levels depending on the structure of the economy. At the same time, small firms contribute to overall job creation mostly when they are young, although only a fraction of start-ups actually participate to job creation (Calvino et al., 2015). As it is likely that cross-country differences in start-up birth and growth rates are related to the possibility for these firms to experiment with new business models and grow or die away, successful policies should target the efficiency of the judiciary, contract enforcement, or the penalties associated to bankruptcies.

Lastly, well-functioning labour market institutions are fundamental to strike the right balance between employment flexibility and aggregate welfare, and to smooth the reallocation of the labour force according to the patterns of GVCs. Active labour market policies should address the match between workers and firms, and allow for a smooth transition between occupations and sectors, as well as between self-employment and salaried employment. Important tools in this sense are policies supporting workforce training, which will be discussed more extensively in the next session. Countries may also need to update their social protection systems, if entitlements are to be made portable from job to job, or if minimum 
levels of employment protection are to be established for all workers. Finally, changes in the relative bargaining power of workers and employers can influence employment flows, as bargaining power is key for the distribution of the gains from international fragmentation of production to workers (e.g. Budd and Slaughter, 2004; Carluccio et al., 2015).

\section{GVCs and Skills}

The studies summarised in this section propose new skills indicators aimed at capturing workers' capabilities and the use of their skills on the job. Furthermore, these studies investigate the relationship between skills and different forms of GVC participation, a link which has never been empirically assessed before, given that past studies defined trade in gross rather than value-added terms.

\subsection{The Trade and Skills Nexus in the Literature}

Value chains' production of high-income countries has become more capital and high-skill intensive after 2001 (e.g. Timmer et al., 2014). While the share of value added accounted for by labour marginally decreased (in favour of capital), this was driven by a major decline in the share of lowand medium-skill labour. As a consequence, developed countries have been specialising in high-skill intensive activities in the value chain.

Such outcomes can be the result of complex mechanisms of mutual feedback between GVCs and skills. On the one hand, high-skilled human capital is expected to carry out complex tasks, which should lead to better economic performance, either directly or through complementarity with technology (Acemoglu and Autor, 2011). Skills increase the capacity to develop and absorb technology and knowledge more broadly, and to better monitor the quality and the organisation of production. On the other hand, GVCs increase the level of competition in the industry or country, thus raising the quality and productivity requirements of production within firms, and possibly the skill endowment of the workforce as a consequence. In Helpman et al. (2017), more productive firms are also able to better screen the potential new employees, thus hiring more skilled workers.

The process of knowledge diffusion across borders and sectors further requires that the workforce upgrades its knowledge stock continuously. Within-firm skill intensity in OECD countries may also increase as a consequence of the offshoring of unskilled labour -intensive tasks to low-income countries. Lastly, the stronger competition caused by GVC participation, may force the least productive firms out of the market; if those that remain are not only the more productive but also the most skill intensive companies, the average skill intensity of the industry and country is bound to increase.

The complex patterns characterising the relationships between skill endowment, tasks performed on the job, and GVCs have thus far been 
explored by only a relatively small number of studies. Furthermore, in these studies, skills are normally measured using information on the educational attainment of the workforce or on the basis of the occupational title of workers. Ingram and Neumann (2006) and Poletaev and Robinson (2008), among others, maintain that both these proxies do not measure skills adequately, at least as far as wage analysis is concerned.

\subsection{A New Characterisation of Skills}

Grundke et al., 2017a exploit data from the Survey of Adult Skills (PIAAC) to propose a number of indicators capturing workers' cognitive skills, personality traits and skills as they emerge from the tasks performed on the job. These indicators are exploited in a descriptive analysis of the skill intensity of industries and occupations as well as in a regression analysis that investigates the relationship between industries' skill intensities, labour productivity, and industries' participation in GVCs. The paper describes the economic importance of all these different types of skills, which had never been taken into consideration before in their complexity in a single analysis of industry performance.

The analysis relies on data for 31 countries and on information both gathered through administered tests and reported by individuals about their work and the tasks performed on the job. Previous analyses conversely relied on information collected by U.S. job specialists contained in the Dictionary of Occupational Titles (and its successor $\mathrm{O}^{\prime} \mathrm{Net}$ ) (Ingram and Neumann, 2006, and Poletaev and Robinson, 2008). Most relevantly, Grundke et al. (2017a) exploratory factor analysis à la Conti et al. (2014) extracts six task-based skill indicators capturing the skills that are key for performance on the job and for firm performance. These skill indicators, which are clearer to interpret and sharper to distinguish from each other than the ones identified by previous studies, relate to: information and communication technologies (ICT) skills; readiness to learn and creative problem solving; managing and communication; self-organisation; marketing and accounting; and science, technology, engineering and mathematics (STEM)quantitative skills.

Figure 6 offers an example of the differences that emerge in the skill endowment of the workforce. It plots the minimum, average and maximum value of ICT skills in the considered occupation and macrosector (manufacturing in dark grey, services in light grey) across countries. While, as expected, high-skill occupations display higher average ICT skills than low-skill occupations, median and maximum values for high-skill occupations are very close, suggesting that a few countries display (on average, across all individuals in the sub-sample) significantly low skill intensity. This is important, as differences in ICT skills are found to play a role in the ability of countries to participate in GVCs. Grundke et al. (2017a) provide a more extensive characterisation of the distribution of skills by age, gender and size of the firm where the individual works. 
Figure 6. ICT skills by occupation, 2011 (Dispersion of country-industry averages by occupation)

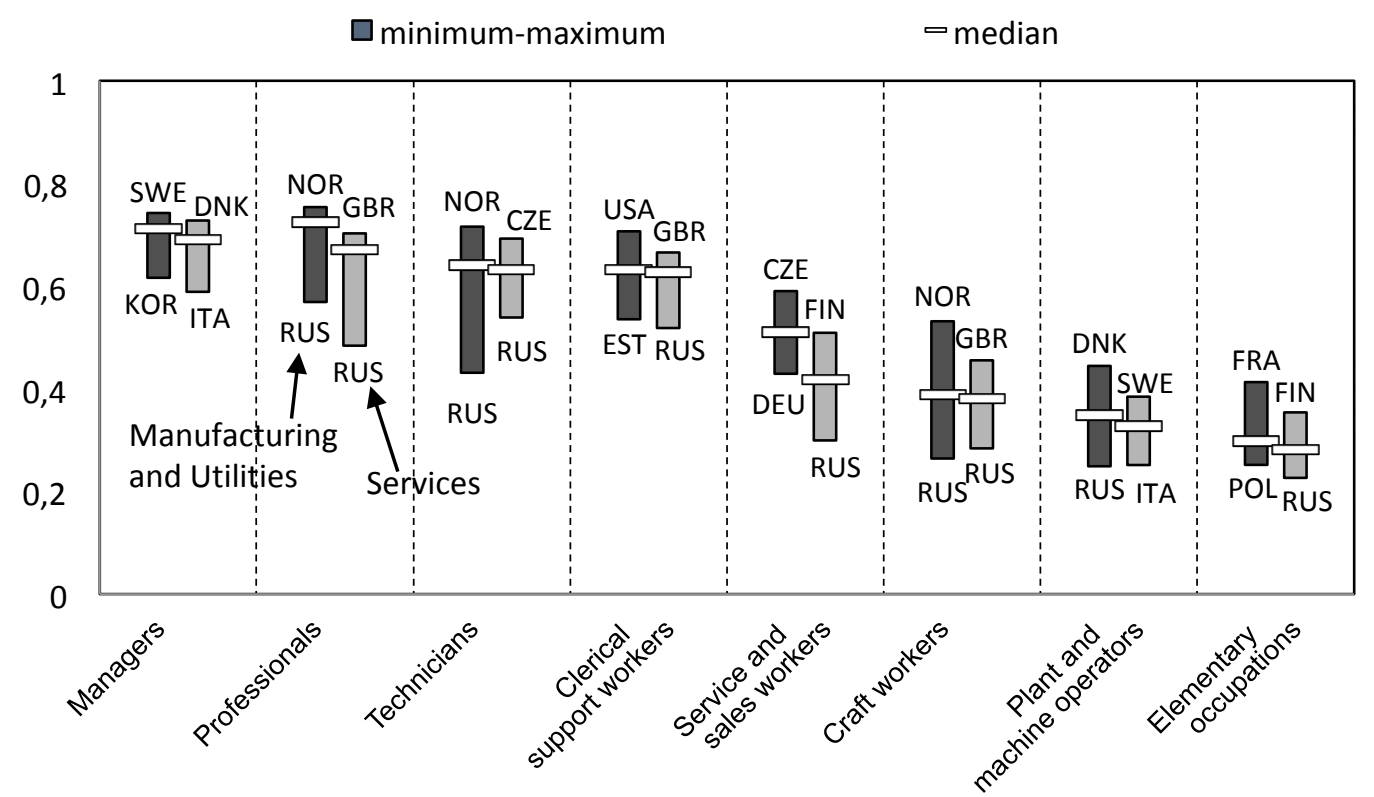

Note: Figures are based on country and sector specific averages, by occupational category. Each bar shows the country exhibiting the minimum and maximum country-sector-occupation value, as an average over all individuals in the country-sector-occupation cell. The sample for this graph includes the following 23 countries from the first round of PIAAC: Australia, Austria, Belgium (Flanders), Canada, the Czech Republic, Germany, Denmark, Estonia, Finland, France, Ireland, Italy, Japan, Korea, the Netherlands, Norway, Poland, the Russian Federation (excluding Moscow), the Slovak Republic, Spain, Sweden, the United Kingdom (England and Northern Ireland), the United States. Country-industry cells having less than 25 observations in PIAAC are excluded to reduce measurement error.

Source: Grundke et al. (2017a) based on PIAAC dataset.

\subsection{Skills, Productivity and Trade Specialisation}

Heterogeneity in skill distributions across countries and industries contributes to explain differences in economic performance and trade patterns. One of the contributions of this work is to specify which skills matter, and thus to add further elements to existing studies agreeing on the importance of skills for economic outcomes. Figure 7a proposes a preliminary answer to this question in the form of controlled correlations between average skills and labour productivity, at the country-industry level. More precisely, it plots the change in labour productivity corresponding to a $1 \%$ increase in average workers' skills for a sample of 18 manufacturing and service industries in 31 OECD and non-OECD 
countries $^{5}$. The correlations control for a number of industry characteristics (see bottom of Figure 7a) and are driven by cross-industry differences in skill endowments.

Industries with a higher mean in any skill but self-organisation display higher productivity, coherently with the idea that more skilled workers are fast learners and can perform their working tasks better6. This association is much stronger for the assessed cognitive skills (literacy, numeracy and problem solving) than for task-based skills. It is partly driven by a compositional effect (not all industries require ICT, STEM or marketing and accounting skills equally to raise efficiency, contrary to cognitive skills), but also suggests that firms cannot operate efficiently if workers are missing the fundamental skills to understand, analyse and solve problems. Furthermore, the results indicate that industries specialising in specific tasks and requiring the corresponding task-based skills more intensively are also more productive than other industries.

5 For the analysis, all 31 countries from the first and the second round of PIAAC are included. Data correspond to the years 2011-12 for the first round of PIAAC and to the 2014-15 for the second round. Furthermore, as TiVA data are not available beyond the year 2011, productivity and trade in value added data for 2011 are used also for the countries from the second round of PIAAC. In robustness checks, where second round countries are excluded, inference from the estimations is preserved.

6 Other aspects of the economy may be driving this relationship. It could be the case that only the high-skill intensive and high productive firms can survive competition on the output market, thus increasing in size and driving both average skill intensity and productivity in the sector. It is also possible that more productive firms attract more skilled workers, or are better able to screen workers at the moment of hiring (Helpman et al., 2017). Lacking firm-level information on workers' skills, these distinctions cannot be made in Grundke et al. (2017a). 
Figure 7a. Correlations between skills and productivity. PIAAC countries, 2011 and 2014

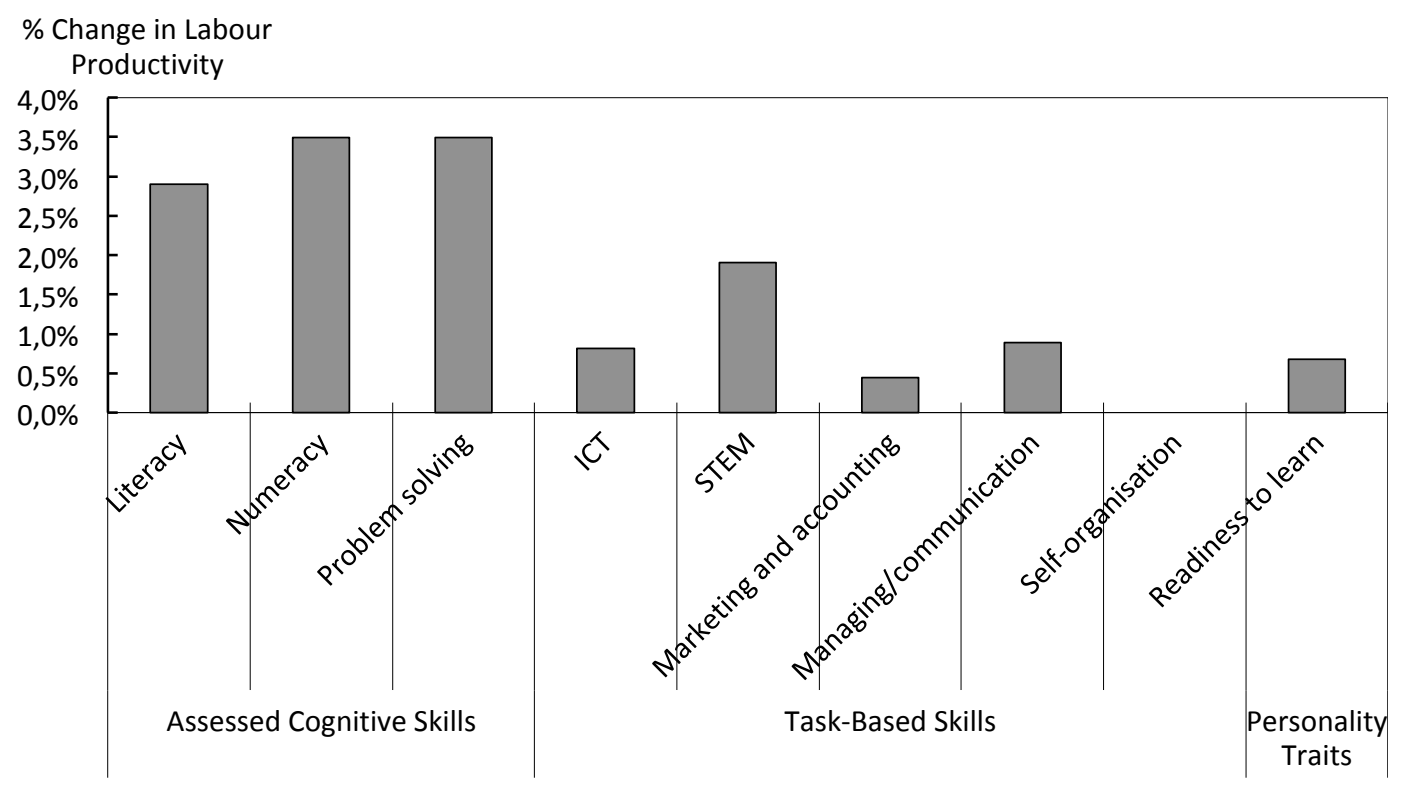

Note: The dependent variable is the log of labour productivity in the TiVA18 sector for the year 2011, measured as value added per employee. All specifications are estimated using OLS and include dummies for countries as well as country-industry control variables (skill intensity, capital intensity and R\&D expenditure). Each skill indicator enters alone in each separate regression, and is measured as the logarithm of the average skill value among workers in the country-industry of reference. The sample includes the same countries as in Figure 6, which were surveyed between 2011 and 2012, but also Chile, Greece, Israel, Lithuania, New Zealand, Singapore, Slovenia and Turkey, which were surveyed between 2014 and 2015. Country-industry cells having less than 25 observations in PIAAC are excluded to reduce measurement error. Standard errors are clustered at the country level. A missing value indicates that the regression coefficient is insignificant at $5 \%$ confidence level.

Source: Grundke et al. (2017a) based on OECD PIAAC, TiVA, SNA, ANBERD data, and WIOD.

Figure $7 \mathrm{~b}$ instead provides a set of correlations between average industry skills and exports in gross and value added terms as well as forward linkages in GVCs (that is, the value added produced in the home country-industry and exported and consumed abroad). The estimation uses a bilateral country-industry gravity model (e.g. Chor, 2010), whereby trade is explained by physical capital intensity, skill intensity, and R\&D expenditure as before, as well as measures of barriers to trade (distance, contiguity, common language, common coloniser, past and current colonial links and being the same country), the size of the two trading countries' industries, and a set of country and partner country dummies (see Grundke et al, 2017a, for more details on the estimation strategy). 
When workers have higher cognitive, ICT or STEM skills, and stronger readiness to learn, countries add more value to exports and participate more in GVCs by specialising in industries that require these skills more intensively. This is also true for managing and communication as well as marketing and accounting skills, but only when trade is measured in value added terms and taking into account indirect exports.

Figure 7b. Correlations between Skills and Participation in GVCs. PIAAC Countries, 2011 and 2014

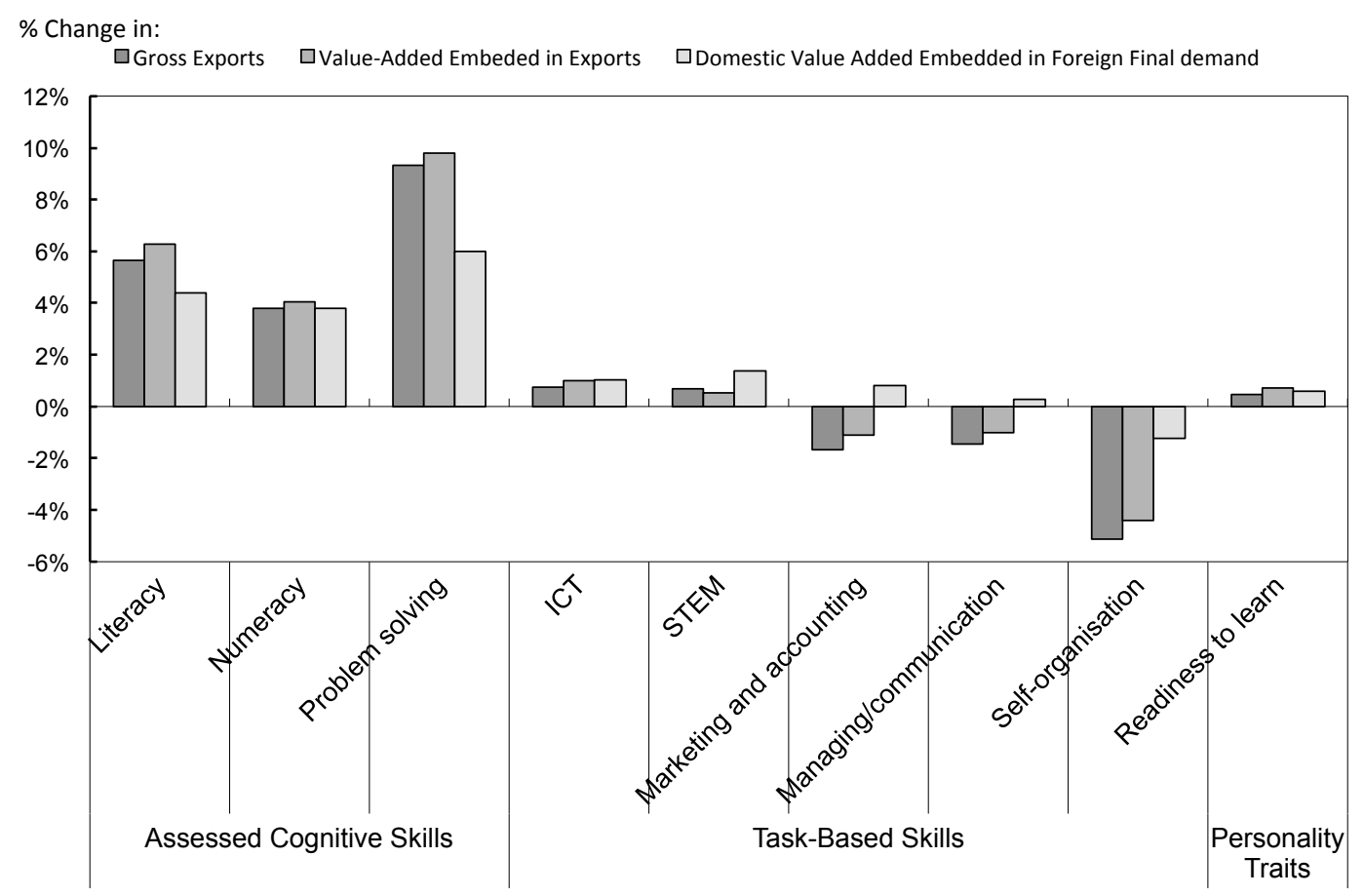

Note: All dependent variables are measured for industry $k$ in home country $i$ and partner country $j$ for the year 2011, and expressed in logarithms. All specifications are estimated using OLS and include dummies for countries as well as country-industry control variables (skill intensity, capital intensity and R\&D expenditure), bilateral trade cost variables, and proxies for the size of the home and foreign country-industry. Each skill indicator enters alone in each separate regression, and is measured as the logarithm of the average skill value among workers in the country-industry of reference. The same countries are included as in Figure 7A. Country-industry cells having less than 25 observations in PIAAC are excluded to reduce measurement error. Standard errors are clustered at the home country - partner country level. A missing value indicates that the regression coefficient is insignificant at $5 \%$ confidence level.

Source: Grundke et al. (2017a) based on OECD PIAAC, TiVA, SNA, ANBERD data, WIOD and CEPII data.

This result is mostly driven by the indirect exports of value added in service industries, which are often traded together with (or as 
intermediate inputs to) manufacturing goods, and do not appear as much in gross export statistics as a consequence. Furthermore, Grundke et al. (2017a) also show that in all industries cognitive skills, ICT skills, management and communication skills and readiness to learn have a significant positive effect on productivity and forward integration into GVCs, irrespective of the idiosyncratic characteristics of each industry.

A second analysis exploits the skills indicators above to describe how the skill composition of a country's workforce shapes the patterns of specialisation in GVCs. Grundke et al., 2017b test the theoretical predictions of two models (Ohnsorge and Trefler, 2007, and Bombardini et al., 2012) which investigate the effects of countries' skills distribution on industry specialisation and international trade flows.

Empirical studies assessing the determinants of comparative advantage have so far considered skills as a single dimension, usually measured in terms of educational attainment, and maintained that human capital differences across countries are based on aggregate or average skills. This entailed ignoring the underlying distribution of skills in the workforce. Bombardini et al.'s (2012), on the contrary, show empirical results that the within-country dispersion of skills matters for industry specialisation in international trade. Ohnsorge and Trefler's (2007) theoretical model focuses instead on the importance of a mix of various skills at the worker level (the skill bundle) and of the country-wide joint distribution of skill bundles for countries' comparative advantage in international markets.

Grundke et al. (2017b) finds empirical support for both these economic relationships, taking a trade-in-value-added perspective and analysing 23 OECD and non-OECD countries. It shows that, for international trade, skill bundles matter much more than individual skills. For instance, ICT industries benefit especially from bundling quantitative or STEM skills with communication and team-working skills. Grundke et al. (2017b) also highlights that the distribution of skills, both when taken singularly and in bundles, is an important determinant of a country's specialisation and performance in GVCs. While the wealth of estimated results makes it impossible to give an appropriate account of all combinations of skills and related paths of GVC specialisation here, Grundke et al. (2017b) show that two countries with similar average skill endowments may end up specialising in different industries and may position themselves at different production stages along GVCs, depending on the way skills are bundled in the workforce.

Taken together, the results presented in the two skills-related analyses discussed above highlight the existence of strong relations between the international fragmentation of production and skills, whether these are intended as (i) averages of different types of skills in the industry; (ii) bundles of different skills; or (iii) the distribution of single skills or of bundles of skills in the industry and country. Education and skill policies should therefore acknowledge the importance of all these aspects, when considering how they can sustain the integration of a country in GVCs.

GVCs are creating new opportunities and challenges for skills development. For countries to better integrate into and benefit the most 
from their connection to international production networks, education policies should aim at equipping all citizens with literacy, numeracy and problem-solving skills, as well as ICT skills, managing and communication skills and a general readiness to learn (see Grundke et al., 2017a, for more details on these results). This in turn calls for the need to guarantee the quality of general education, throughout the lifetime of individuals, the removal of barriers to access education and life-long learning, and improvements in the recognition of skills.

Advanced education programs should help students develop both subject-specific skills and creativity, critical thinking, and communication skills. Policies focusing only on selected specific skills rather than bundles of skills may reduce the ability of countries to appropriate the benefits of GVC participation. This may require, among others, adapting the curricula in tertiary education to combine the teaching of cognitive and soft skills.

Insofar as the development of bundles of skills makes workers more flexible in their learning and activation of skills on the job, these policies would enhance workers' mobility across occupations and sectors of the economy. Mobility is fundamental to reduce the cost of the displacement caused by offshoring and import competition. Rethinking public support to vocational education and training and assessing the results obtained would help understand whether the resources were spent efficiently and reached the most appropriate targets. Special attention should be given to the training of unskilled workers, who seemingly face the highest risk of displacement but are usually the least likely to receive training. Also, strengthening the recognition of the skills that workers acquire on the job (often informally) would help raise mobility, albeit at the price of a higher risk of possible poaching of a firm's employees by a competing firm.

Life-long learning and training should target the skill needs required by the evolutions of a country's production structure. Policies targeting the development of a given industry can be inefficient and reduce a country's comparative advantage if skills do not match the requirements of the industry. As a consequence, effort should be put in understanding and anticipating the skills required in production, and how to effectively deploy the existing human capital. This, in turn, requires strengthening the coordination between the private sector and the education system.

Ultimately, the different branches of government should come together, too. For instance, sound education and life-long learning policies may not boost productivity and trade if firms are hindered in their experimentation and innovation efforts, or lack appropriate managerial capabilities to understand the challenges imposed by GVCs and activate the appropriate skills as a consequence, point which is further developed in the next section.

\section{GVCs and Knowledge Based Capital}

The fragmentation of production across borders demands economic agents to review the way they operate. Workers may need to re-train and 
perhaps change job to avoid unemployment or enhance their careers in a labour market where many employers operate on the international market. Firms may need to adapt to stronger competition at home, find a way to exploit new inputs produced abroad, or evolve to penetrate new markets. This in turn calls for the need to increase firms' capabilities to be able adapt to international markets, and to invest in knowledge based capital assets. Three types of knowledge-based capital assets are generally considered (Corrado et al., 2005): computerised information (software and databases); innovative property ( $\mathrm{R} \& \mathrm{D}$, copyrights, designs); and economic competencies (including brands and advertising, firm-level training, and organisational know-how).

\subsection{The trade and $K B C$ nexus in the literature}

Multiple aspects of investment in KBC can be related to an industry's performance in GVCs. These include upgrading the quality of products, creating value in upstream activities such as new concept or product development, as well as engaging in downstream activities related to bringing products onto markets such as marketing, branding or customer service (OECD, 2013a and 2013b). A number of existing studies have also estimated the positive contribution of knowledge-based capital deepening to labour productivity (e.g. Corrado et al., 2013) and OC and ICT in particular (Bresnahan et al., 2002; Bloom et al., 2012). While the arguments proposed here can apply to many KBC assets, for analytical purposes the contribution below focuses on investment in organisational capital (OC) in particular, i.e. on investments in firm-specific human capital which affects the medium and long-term functioning of firms ${ }^{7}$.

Better organisational capabilities, especially if coupled with a better communication infrastructure, can enhance firms' ability to co-ordinate with and monitor suppliers, integrate inputs of different quality or technological content into production, and better match workers with tasks in production (e.g. Bloom et al., 2016). Outsourcing and offshoring of intermediate inputs, in turn, can stimulate investment by providing access to greater variety of inputs, by reducing costs and freeing resources for investment, or by increasing the pace of reallocation across agents within

7 Other recent OECD work provided a new methodology to estimate industry investment in another $\mathrm{KBC}$ asset, firm-based training, for a number of OECD countries for 2011 (Haskel et al., 2016). However, data availability requirements make it impossible to develop a reliable time series of investment, which is instead necessary for the analysis in Marcolin et al. (2018b). 
and across sectors, thanks to competition (e.g. Bloom et al., 2015; CAE, 2015)8.

Such mutually reinforcing dynamics between KBC investment and upstream integration can be dampened by the possibility that in-house production is downsized in favor of production elsewhere, to such an extent that also investment in $\mathrm{KBC}$ gets ultimately reduced at home.

\subsection{KBC-GVC, a two-way relationship?}

Marcolin et al. (2018b) shed light on these complex dynamics by exploring for the first time the double direction of causality linking investment in software and organisational capabilities (OC) to the degree of sourcing of inputs from domestic and foreign suppliers, for both service and manufacturing industries. The analysis, which encompasses 25 OECD countries and 26 non-agriculture industries for the period 2000-11, uses measures of backward linkages from the WTO-OECD Trade in Value Added dataset and the underlying Inter-country Input-Output (ICIO) tables.

Investment in OC captures the amount that industries devote to the compensation of workers whose occupations are intensive in managerial and organisational tasks, based on new cross-country information on workers' task on the job contained in the OECD PIAAC survey (methodology in Le Mouel et al., 2016).

The new OC investment data estimated in panel format in Le Mouel et al., 2016 reproduces a well-established fact, i.e. that communication and

8 The analysis of the relationship between KBC investment and forward linkages is not covered by the project at this stage. Previous OECD work (OECD, 2013a and 2013b) provided evidence of the correlation between KBC stocks in selected OECD countries and value added of exports.

9 The concept which is here denoted as organisational capital has been defined in a variety of ways in previous studies, even when focusing on managerial and human resource practices more narrowly. For a review of measures of organisational capital and managerial capabilities, see for instance Bloom et al. (2014). In Marcolin et al. (2018b) OC is defined as the firm-specific human capital performing tasks such as: developing objectives and strategies; organising, planning and prioritising work; building teams, matching employees to tasks, and providing training; supervising and coordinating activities; and communicating across and within groups to provide guidance and motivation (after Le Mouel et al., 2016). The sample is restricted to selected European countries and the U.S. because constructing panel estimates of investment in OC requires the availability of matrices of employment by disaggregated sector and occupations, in internationally comparable classifications. Access to such data is limited at present. 
information capabilities in an industry are complementary to organisational capabilities (Figure 8). Firms' and industries' productivity returns to ICT investment are greater when firms are able to adjust the production structure to the new information and communication infrastructure. Marcolin et al. (2018b) show that this relationship holds, at a descriptive level, when the concept of ICT is extended to include not only tangible equipment but also software investment and purchases of intermediate ICT services.

Marcolin et al. (2018b) show that investment in OC and software is complementary to offshoring, in net value added terms, once changes in labour productivity, tangible investment, employment and cost of employees are accounted for. Such a complementarity, to be intended as the ability of each activity to increase the return to the other, may arise out of firms' improved ability to absorb exogenous shocks, to match workers with technology, and to adapt production processes - especially if offshored inputs are of different quality or technological content than domestic production.

Greater offshoring of inputs, in turn, may further enhance investment in OC and software through channels such as greater foreign competition on the input market, or by requiring more coordination and flexibility, or by raising the technological content of production.

Figure 8. Correlation of 2000-2010 Growth in OC Investment and in ICT

(a) ICT hardware

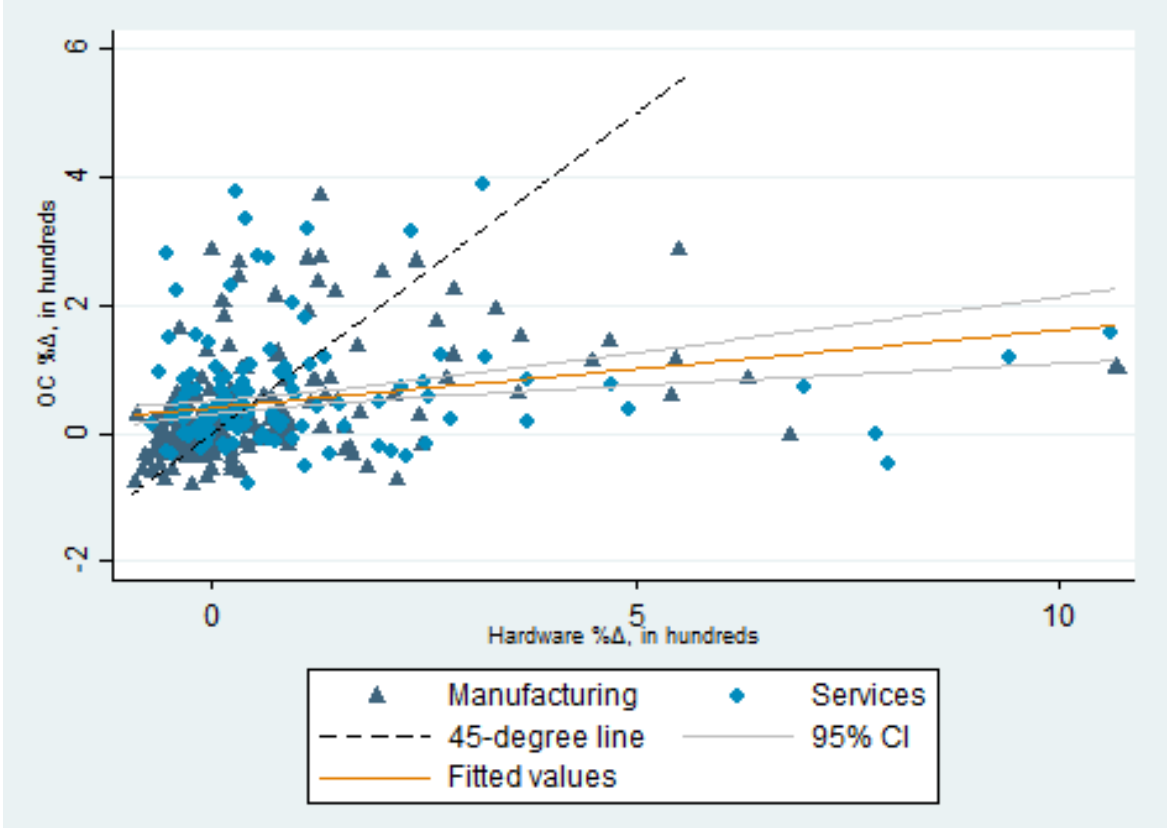




\section{(b) ICT software}

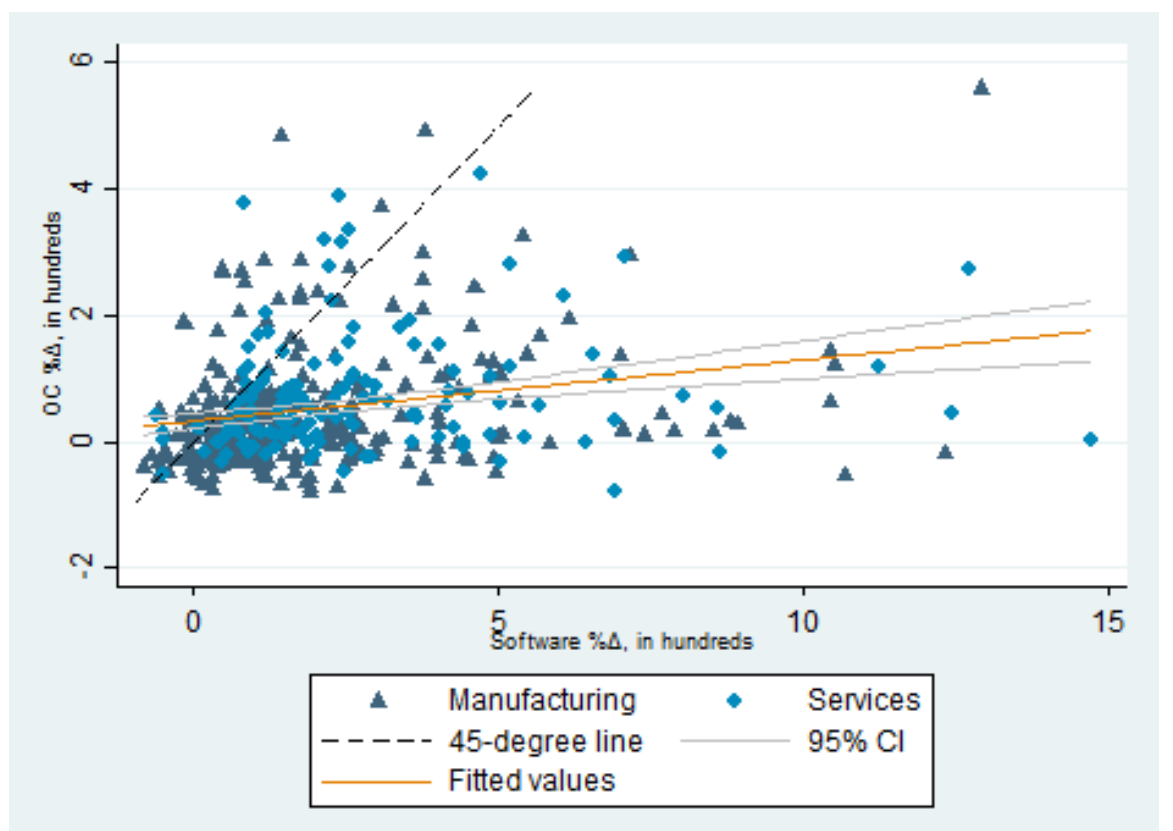

Note: Dots represent industry-country pairs. Dots coloured in dark blue refer to manufacturing industries, those in light blue to services. ICT hardware includes investment (SNA) and purchases of ICT from ISIC rev.3 industries 30, 32, 33. ICT software includes investment (SNA) and purchases of ICT services from ISIC rev. 3 industry 72. All figures are net of the purchases of ICT inputs by the sectors $30,32,33$ and 72 .

Source: Marcolin et al. (2018b) based on PIAAC, EU LFS, SES, CPS, SNA, and ICIO data.

On the one hand, backward linkages with international markets may provide access to the frontier of knowledge in the sector. On the other hand, KBC investment may help spreading and embedding this knowledge into domestic production.

The analysis thus suggests that KBC investment and GVC integration may be reinforcing each other. This should not be surprising in light of the extensive literature linking productivity, KBC investment and GVC at the firm or at more aggregate levels. The analysis therefore contributes to the debate on the dynamics of aggregate productivity in OECD countries. From what mentioned above, productivity enhancements within firms can stem from the ability of KBC investment to generate and diffuse ideas, some of which are embodied in inputs provided by the production chain or are stimulated by increased competition in the input market. But KBC investment and GVC linkages can also impact the reallocation of resources between best and worst performing firms, and aggregate productivity as a consequence (e.g. Bloom et al., 2015).

The analysis in Marcolin et al. (2018b) stresses one of the positive returns to outsourcing and offshoring, i.e. that they can stimulate the economy's investment in knowledge based capital assets. In order for this specific channel of gains from internationalisation to materialise, firms 
should be able to invest in knowledge according to their preferred business strategy.

On the one hand, this may call for enhanced market competition and for the removal of barriers to the free allocation of labour and capital among firms. Product market reforms enabling more rapid diffusion of technology and information, and increased incentives for firms to innovate and adapt production to the international market may be helpful in this respect. These framework conditions may be especially important in light of the complementarity between $\mathrm{KBC}$ investment and the GVC integration highlighted above, as the latter may strengthen winner-takes-all dynamics and increase market power in case only few firms are able to innovate and exploit the benefits of international integration. A fair integration in GVCs should not produce a market dominated by few firms able to extract most of the consumer surplus, block entry of competitors and weaken the process of creative destruction.

On the other hand, policy may want to broaden its efforts in support of the creation and diffusion of knowledge. For overall KBC assets, this implies considering which mechanisms enhance the recognition and assessment of the intangible asset by the market (without risking to reveal strategic information), as well as what taxation design is best suited to stimulate investment. Similar conclusions are drawn in OECD (2013b) which investigated KBC more broadly and the links with forward GVC participation in particular. What is more, financial market reforms may facilitate new technology-based entrepreneurial initiatives. Policy makers could also focus on how to endow the workforce with the necessary skills, and in particular entrepreneurship skills and managerial capabilities, which both support the diffusion and absorption of new technologies, and help firms adapt to the challenges of production in an international production chain.

The case for coordination among different branches of policy making, already mentioned above, should be made here even more strongly. As $\mathrm{KBC}$ investment enhances the ability of the economy to create and absorb knowledge, innovation, skill and trade policies should be jointly declined (to the extent possible), in order to maximise the benefits of participating in international production chains. When evaluating whether to further liberalise trade and investment, OECD countries should consider the possible gains in terms of knowledge creation and absorption, too. Similarly, it should not come as a surprise if incentives to innovation and investment in knowledge raise a firm's propensity to split its production process across borders.

\section{Conclusions}

This paper proposes a synthesis of different streams of analysis investigating the role of GVCs in shaping demand for labour and skills in OECD countries. While evidence suggests that the international fragmentation of production has benefitted OECD countries in the aggregate, it has left parts of society behind, also due to the insufficient 
attention paid to redistribution issues. Combined with other market failures like rigidities in input and product markets, credit market imperfections, and dynamics related to the pace of technological change, integration in GVC has in some cases contributed to lower the working and living conditions of parts of the population.

Responding to these societal challenges and allowing the benefits from globalisation to both materialise to the greatest extent and be distributed equitably, OECD countries should activate or step up actions in multiple policy making areas. Key ones concern education and life-long learning, to bring back people and their skills at the centre, for society as a whole to gain from this form of globalisation. While it is unlikely that any policy may influence features like the degree of computerisation of employment directly, improvements in the way pupils and workers are prepared to the challenges jointly raised by GVCs and technological change would enhance workers' ability to integrate in the labour market, perform and transit successfully between jobs, if needed. Life-long learning initiatives should bear in mind that while general cognitive and ICT skills are very important for employability and performance, so are non-cognitive skills. Also, the evidence generated the importance of skill bundles for industry's performance, i.e. the need that each and every worker is endowed with more than one set of skills, for firms to thrive in GVCs.

Strengthening the entrepreneurial skills and managerial capabilities of the population should enhance the firms' and industry's ability to adapt to the challenges of international production chain, and to better cope with a constant need to generate and embed technological advances in production processes.

Well-functioning labour market institutions are also important to enhance the reallocation of the labour force and thus maximally benefit from participation and positioning in GVCs. Active labour market policies coupled with workers' training can help address the match between workers and firms, and allow for a smooth transition between occupations and sectors, as well as between self-employment and salaried employment. The challenging transitions between occupations and sectors may further require updates in the design of social protection, e.g. by making entitlements portable from job to job, or by amending collective agreements or minimum levels of employment protection of workers.

As GVCs facilitate the diffusion of knowledge and technology across countries and sectors, and the evidence provided in this project stresses the importance of innovation for job creation, policy makers may want to broaden their efforts in sustaining the creation and diffusion of knowledge. This calls for new approaches to science, technology and innovation policies, as well as for the removal of existing barriers to firm entry and to the need to re-think competition policy. A fair integration in GVCs should not result into markets dominated by few firms able to extract most of the consumer surplus, block entry of competitors and weaken the process of creative destruction.

Above all, sound policy approaches to addressing the societal problems triggered by globalisation cannot but rely on coordinated policy 
interventions. For instance, when discussing further trade and investment liberalisation, OECD countries should consider, among others, the possible gains in terms of knowledge creation and absorption, as well the cost in terms of employment reallocation such reforms may impose. Lack of consideration of the important spillovers between industrial, innovation, labour, trade and skills policies may partially or totally invalidate policy actions, and both reduce the aggregate gains from GVCs as well as worsen their (re)distribution among different layers of society.

Lastly, the analyses above suggest that globalisation and technological progress are intertwined, and often mutually reinforcing. The progressive digital transformation of production in OECD countries is already playing and is likely to play an even more important role in the future. Coupled with the ongoing progressive globalisation, the digital transformation is going to impact economies and societies profoundly, including labour markets and skills. This may happen through multiple channels, some of which are: knowledge creation and transmission, big data and digital trade, also across borders; the convergence of service and goods production; and the substitution of physical with digital or intangible products and capital. Such transformation increases the urgency of coordinated policy actions aimed to make globalisation beneficial for all.

\section{References}

Arkolakis, C., Costinot, A., Rodriguez-Clare, A., 2012. New Trade Models, Same Old Gains?, American Economic Review 102(1), 94-130.

Acemoglu, D., Autor, D., 2011. Skills, Tasks Technologies: Implications for Employment and Earnings. In Ashenfelter, O. and Card, D., editors, Handbook of Labor Economics 4, 773-1823.

Autor, D. 2015. Why Are There Still so Many Jobs? The History and Future of Workplace Automation, The Journal of Economic Perspectives 293, 3-30.

Autor, D. 2013. The 'Task Approach' to Labor Markets: An Overview, Journal of Labour Market Research 46, 185-199.

Autor, D.H., Levy, F., Murnane, R., 2003, The Skill Content of Recent Technological Change: An Empirical Exploration, Quarterly Journal of Economics 118(4), 1279-1333.

Autor, D., Dorn, D., Hanson, G., 2016. The China Shock: Learning from Labor Market Adjustment to Large Changes in Trade, Annual Review of Economics 8, 205-240.

Autor, D., Dorn, D., Hanson, G., 2013. The China Syndrome: Local Labor Market Effects of Import Competition in the United States, American Economic Review 103(6), 2121-2168. 
Autor D., Dorn, D., Hanson, G., Majlesi, K., 2016. Importing Political Polarization? The Electoral Consequences of Rising Trade Exposure. MIT Working Paper.

Autor, D., Katz, L., 1999. Changes in the Aage Structure and Earnings Inequality. In Ashenfelter, O. and Card, D., editors, Handbook of Labor Economics, volume 3A,1463-1555.

Baldwin, R. E. 2012. Global Supply Chains: Why They Emerged, Why They Matter, and Where They Are Going. Centre for Economic Policy Research Discussion Paper No. 9103.

Berman, E., Bound, J., Griliches, Z., 1994. Changes in the Demand for Skilled Labor within U.S. Manufacturing: Evidence from the Annual Survey of Manufactures. The Quarterly Journal of Economics, 109(2), 367-397.

Berman, E., Bound, J., Machin, S., 1998. Implications of Skill-Biased Technological Change: International Evidence. The Quarterly Journal of Economics, 113(4),1245-1280.

Bloom, N., Draca, M., Van Reenen, J., 2015. Trade Induced Technical Change? The Impact of Chinese Imports on innovation, IT and Productivity. Review of Economic Studies, 83(1): 87-117.

Bloom, N., Lemos, R. Sadun, D., Scur, D., Van Reenen, J., 2014. Jeea-Fbbva Lecture 2013: The New Empirical Economics of Management. Journal of the European Economic Association, 12/4, 835-876.

Bloom, N., Manova, K., Van Reenen, J., Sun, S., Yu, Z., 2016. Managing Trade: Evidence from China and the US. mimeo.

Bloom, N., Sadun, R., Van Reenen, J., 2012. Americans Do IT Better: US Multinationals and the Productivity Miracle. American Economic Review, 102/1, 167-201.

Breemersch, K., Damijan, J.P., Konings, J., 2017. Labor Market Polarization in Advanced Countries: Impact of Global Value Chains, Technology, Import Competition from China and Labor Market Institutions", OECD Social, Employment and Migration Working Papers 197, OECD Publishing.

Bresnahan, T.F., Brynjolfsson, E., Hitt, L.M., 2002. Information Technology, Workplace Organization, and the Demand for Skilled Labor: Firm-Level Evidence. Quarterly Journal of Economics 117/1, 339-376. 
Bombardini, M., Gallipoli, G., Pupato, G. 2014. Unobservable Skill Dispersion and Comparative Advantage. Journal of International Economics 92(2), 317-329.

Budd, J.W., Slaughter, M.J. 2000. Are Profits Shared Across Borders? Evidence on International Rent Sharing. NBER Working Papers No. 8014.

Calvino, F., Criscuolo, C., Menon, C., 2015. Cross-Country Evidence on Start-Up Dynamics. OECD Science, Technology and Industry Working Papers, 2015/06, OECD Publishing, Paris. http: / / dx.doi.org/10.1787/5jrxtkb9mxtb-en.

Carluccio, J., Fougère, D., Gautier, E., 2015. Trade, Wages and Collective Bargaining: Evidence from France. Economic Journal, Royal Economic Society 125(584), 803-837.

Chor, D. 2010, Unpacking Sources of Comparative Advantage: A Quantitative Approach. Journal of International Economics 82, 152-167.

Colantone, I., Stanig, P., 2016. Global Competition and Brexit. BAFFI CAREFIN Centre Research Paper 2016-44.

Conti, G., Frühwirth-Schnatter, S., Heckman, J.J., Piatek, R., 2014. Bayesian Exploratory Factor Analysis. Journal of Econometrics 183(1), 31-57.

Corrado, C., Haskel, J., Jona-Lasinio, C., Iommi, M., 2013. Innovation and Intangible Investment in Europe, Japan and the United States. Oxford Review of Economic Policy 29/2, 261-286.

Corrado, C., Hulten, C., Sichel, D., 2005. Measuring Capital and Technology: An Expanded Framework in Corrado, C., Haltiwanger, J., and D. Sichel (eds.), Measuring Capital in the New Economy, 11-45, The University of Chicago Press, Chicago, IL.

Council of Economic Advisors of the United States - CEA 2015. The Economic Benefits of U.S. Trade.

Crozet, M., Orefice, G. 2017. Trade and Labor Market: What Do We Know? CEPII Policy Brief 15, CEPII.

Dippel C., Gold, R., Heblich, S., 2015. Globalization and its (Dis-)Content: Trade Shocks and Voting Behavior. NBER Working Paper, No. 21812.

Ebenstein, A., Harrison, A., McMillan, M., Phillips, S., 2014. Estimating the Impact of Trade and Offshoring on American Workers using Current Population Surveys. The Review of Economics and Statistics 96(4), 581-595. 
ECB, 2016. Understanding the Weakness in Global Trade. What is the New Normal? ECB Occasional paper No 178.

Fajgelbaum, P., Khandelwal, A., 2016. Measuring the Unequal Gains from Trade. Quarterly Journal of Economics 131(3), 1113-1180.

Feenstra, R.C. 2016. Advanced International Trade: Theory and Evidence. Princeton University Press.

Feenstra, R.C., Hanson, G., 1999. The Impact of Outsourcing and High-Technology Capital on Wages: Estimates for the United States. The Quarterly Journal of Economics 114(3), 907-940.

Goos, M., Manning, A., Salomons, A., 2014. Explaining Job Polarization: Routine-Biased Technological Change and Offshoring. American Economic Review 104(8), 2509-26.

Grossman, G. M., Rossi-Hansberg, E., 2008. Trading Tasks: A Simple Theory of Offshoring. American Economic Review 98, No. 5, 1978-97.

Grundke, R., Kalamova, M., Keslair, F., Jamet, S., Squicciarini, M., 2017a. Skills and Global Value Chains: a Characterisation, OECD Science, Technology and Industry Working Papers, No. 2017/05, OECD Publishing. http: / / dx.doi.org/10.1787/cdb5de9b-en.

Grundke, R., Kalamova, M., Keslair, F., Jamet, S., Squicciarini, M., 2017b. Having the Right Mix: The Role of Skill Bundles for Comparative Advantage and Industry Performance in GVCs, OECD Science, Technology and Industry Working Papers, No. 2017/03, OECD Publishing, Paris. http: / / dx.doi.org/10.1787/892a4787-en.

Haskel, J., Horvát, P., Marcolin, L., O’Mahony, M., Squicciarini, M., Stavlöt, U., 2016. Societal Competencies. In Corrado, C., K. Jaeger, and C. Jona-Lasinio, editors, Measuring Intangible Capital in the Public Sector: a Manual, 26-80.

Haugh, D., Kopoin, A., Rusticelli, E., Turner, D., Dutu, R., 2016. Cardiac Arrest or Dizzy Spell: why is World Trade so Weak and What can Policy Do about it? OECD Economic Policy Paper No 18. OCDE, Paris. DOI: http: / / dx.doi.org/10.1787/5jlr2h45q532-en.

Heckscher, E.F., et al. 1991. Heckscher-Ohlin Trade Theory. Cambridge, Mass: MIT Press.

Helpman E., Itskhoki, O., Muendler, M., Redding, S., 2017. Trade and Inequality: From Theory to Estimation. Review of Economic Studies 84(1), 357-405. 
Hoekman, B., Winters, L.A., 2005. Trade and Employment: Stylized Facts and Research Findings. Policy Research Working Paper Series 3676, The World Bank.

Ingram, B.F., Neumann, G.R., 2006. The Returns to Skill. Labour Economics 13(1), 35-59.

Jensen B.J., Quinn, D.P., Weymouth, S., 2018. Winners and losers in international trade: The effects on U.S. presidential voting. International Organisation 71(3), 1-35.

Keller, W., Utar, H., 2016. International Trade and Job Polarization: Evidence at the Worker-Level. NBER Working Papers 22315.

Le Mouel, M., Marcolin, L., Squicciarini, M., 2016. Investment in Organisational Capital: Methodology and Panel Estimates. SPINTAN Working Paper No. 21.

Malgouyres, C., 2016. Trade Shocks and Far-Right Voting: Evidence from French Presidential Elections, mimeo.

Marcolin, L., Miroudot, S., Squicciarini, M., 2018a. To Be (Routine) or Not to Be (Routine), That is the Question: a Cross-country Task-based Answer. Industrial and Corporate Change, forthcoming.

Marcolin, L., Le Mouel, M., Squicciarini, M., 2018b. Investment in Knowledge-Based Capital and Backward Linkages in Global Value Chains. OECD Science, Technology and Industry Working Papers, forthcoming, OECD Publishing, Paris.

Marcolin, L., Miroudot, S., Squicciarini, M., 2016. Routine Jobs, Employment and Technological Innovation in Global Value Chains, OECD Science, Technology and Industry Working Papers, No. 2016/01, OECD Publishing, Paris. http: / / dx.doi.org/10.1787/5jm5dcz2d26j-en.

OECD 2015a. OECD Science, Technology and Industry Scoreboard 2015: Innovation for Growth and Society, OECD Publishing, Paris. http: / / dx.doi.org/10.1787/sti_scoreboard-2015-en.

OECD 2015b. The Innovation Imperative: Contributing to Productivity, Growth and Well-Being, OECD Publishing, Paris, http: / / dx.doi.org/10.1787/9789264239814-en.

OECD 2013a. Upgrading in Global Value Chains: The role of Knowledge-Based Capital, in Interconnected Economies: Benefiting from Global Value Chains, OECD Publishing, http: / / dx.doi.org/10.1787/9789264189560-9-en. 
OECD 2013b. Supporting Investment in Knowledge Capital, Growth and Innovation.

OECD Publishing, http: / / dx.doi.org/10.1787/9789264193307-en.

Ohnsorge, F., Trefler, D., 2007, Sorting It Out: International Trade with Heterogeneous Workers. Journal of Political Economy, 115(5), 868-892.

Pew Research Centre 2014. Faith and Scepticism about Trade, Foreign Investment, Report.

Poletaev, M., Robinson, C., 2008, Human Capital Specificity: Evidence from the Dictionary of Occupational Titles and Displaced Worker Surveys, 1984-2000. Journal of Labor Economics 26(3), 387-420.

Timmer, M.P., Erumban, A.A., Los, B., Stehrer, R., de Vries, G.J., 2014. Slicing Up Global Value Chains. Journal of Economic Perspectives 28(2), 99-118. 